\title{
ADULT PERIPHERAL NEUROBLASTOMA
}

\author{
S. L. ROSSITTI * - PATRICIA S. DE MATOS ** - R. J. BALBO *
}

A. R. ZUIANI * - I.R. THOMAZ *

SUMMARY - Report of clinical features, diagnostic and surgical aspects observed in a case of adult peripheral neuroblastoma infiltrative of the lumbosacral plexuses. The patient, a 39-year-old male, presented with sciatalgia and progressive crural monoplegia. Characteristic histological features of this rare tumor are described. Surgical resection was attempted via a posterior transgluteal approach to the retroperitoneum through the greater sciatic foramen.

Neuroblastoma periférico em adulto.

RESUMO - Relato de caso de neuroblastoma periférico em paciente adulto, com 39 anos de idade, do sexo masculino. O tumor de localização retroperitoneal, acometeu o plexo lombos-ᄀ sacral esquerdo. Os primeiros sintomas foram de lombociatalgia, progredindo com monoparesia crural pronunciada e dor incapacitante. São descritas as características histológicas dessa neoplasia rara na idade adulta, incluindo estudo imuno-histoquímico e microscopia eletrônica, bem como a técnica cirúrgica empregada para sua ressecção (via posterior transglú-ᄀ tea, sendo a cavidade pélvica alcançada através do forame isquiático maior). Os neuroblastomas devem ser considerados no diagnóstico diferencial do chamado grupo histológico dos tumores malignos de células pequenas, mesmo em se tratando de pacientes adultos.

Neuroblastomas, essentially recognized as a malignancy of infancy and childhood, do in fact occur in all age groups. The purpose of this paper is to report a case of peripheral neuroblastoma in an adult patient.

\section{CASE REPOR T}

BCB, 39-year-old, male. In January 1989 the patient noticed pain and paresthesiae on his left hallux, dorsomedial portions of the foot and medial portion of the, leg, on the left side. The pain was provoked by stretching of his left lower limb when walking, and on stooping; it progressively increased on the next weeks, radiating also to the left buttock and low back region, with ensuing disability. In June 1989, a computerized tomographic (CT) scan of the lumbosacral spine and pelvis revealed a tumoral mass on the left, at the site of the lumbosacral nerve plexuses. A laparotomy was done> revealing that the tumor waa intensely adherent to the rectum, left ureter and nerve plexuses; considered inoperable, the tumor was just biopsied. Histologic diagnosis was peripheral neuroblastoma (Fig. 1). He underwent chemotherapy. In spite of this, the patient cursed with progressive severe motor and sensitive loss on the left lower limb, and sexual impotence. Repeated CT-scan (June 1990) of the pelvis showed a Large retroperitoneal mass on the left, infiltrative of the piriformis and compressing the rectum (Fig. 2). By this time, excruciating pain on the left buttock, lower limb and low back region required morphine administration-through an epidural catheter (Hitchcock's Pain Classification: Grade 5). The. patient was referred to the Neurosurgical Unit in July 1990, considering the possibility of surgical pain relief. There was no sign of distant neoplasic spread. Neurologic examination - Left crural flacid mono-

Departamento de Neuro-Psiquiatria (*) e de Anatomia Patológica (**) Faculdade de Ciências Médicas, Universidade Católica de Campinas (PUCCAMP).

Dr. Roque J. Balbo - Departamento de Neurocirurgia, Hospital Vera Cruz - Av. Andrade Neves 402 - 13020 Campinas SP - Brasil. 

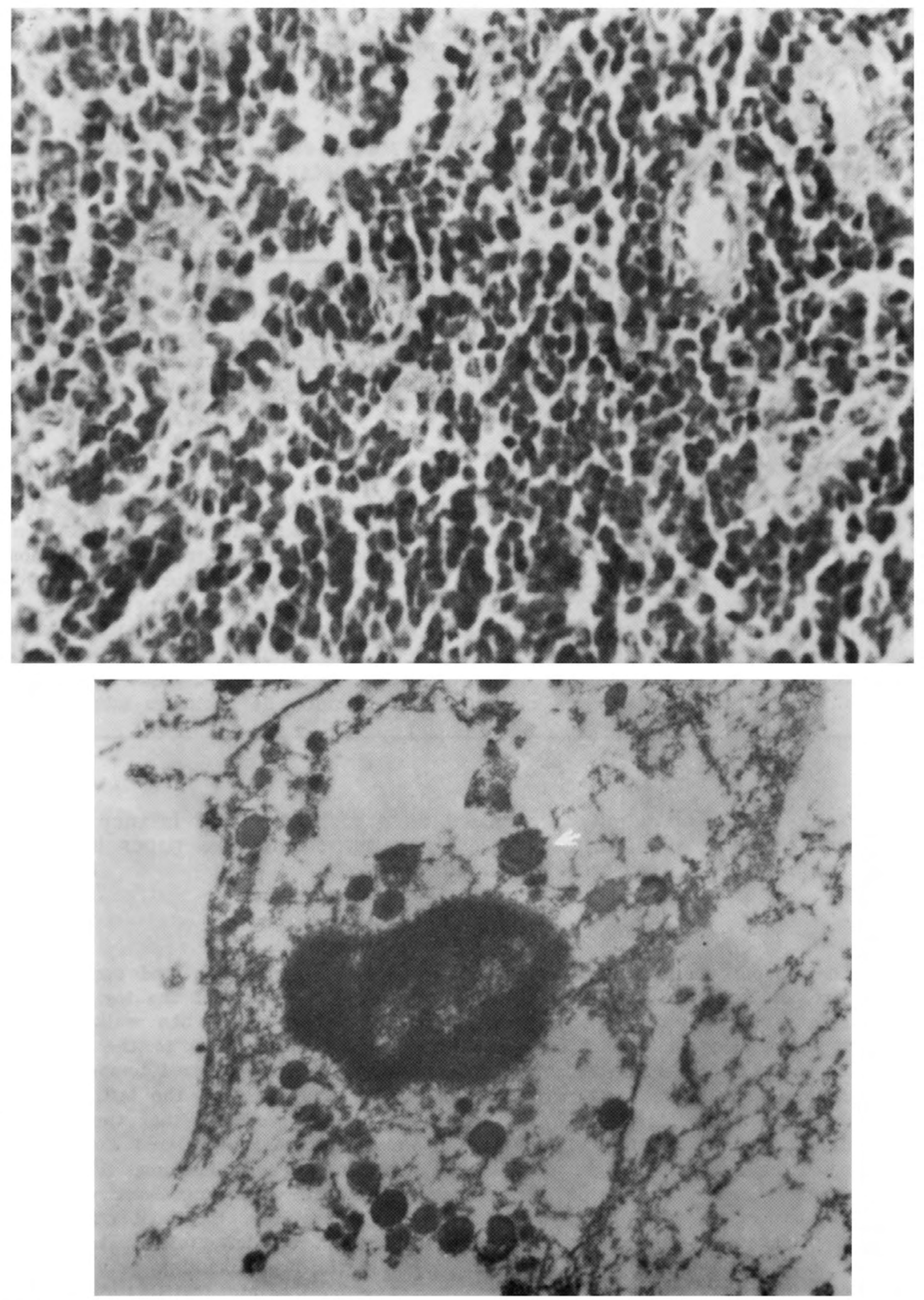

Fig. 1 - Case BCB. Peripheral neuroblastoma, microscopic examination. Small-cell neoplasia of difuse citoarchitectural type. Various sized nodular areas with vascular rosette-like cell arrangement. Reticulin-stained preparation showed a fine intercellular fibrillary matrix. PAS stain was negative. Avidin-Biotin-Peroxidase tests were positive for Neuron-Specific Enolase, 1:500, and for S-100 Antigen, 1:1000. A (above), $H$. \& E. preparation; $B$ (below), electron microscopic preparation of the formalin-fixed material; note dense core neurosecretory granules in the citoplasm of a neoplasic cell. 


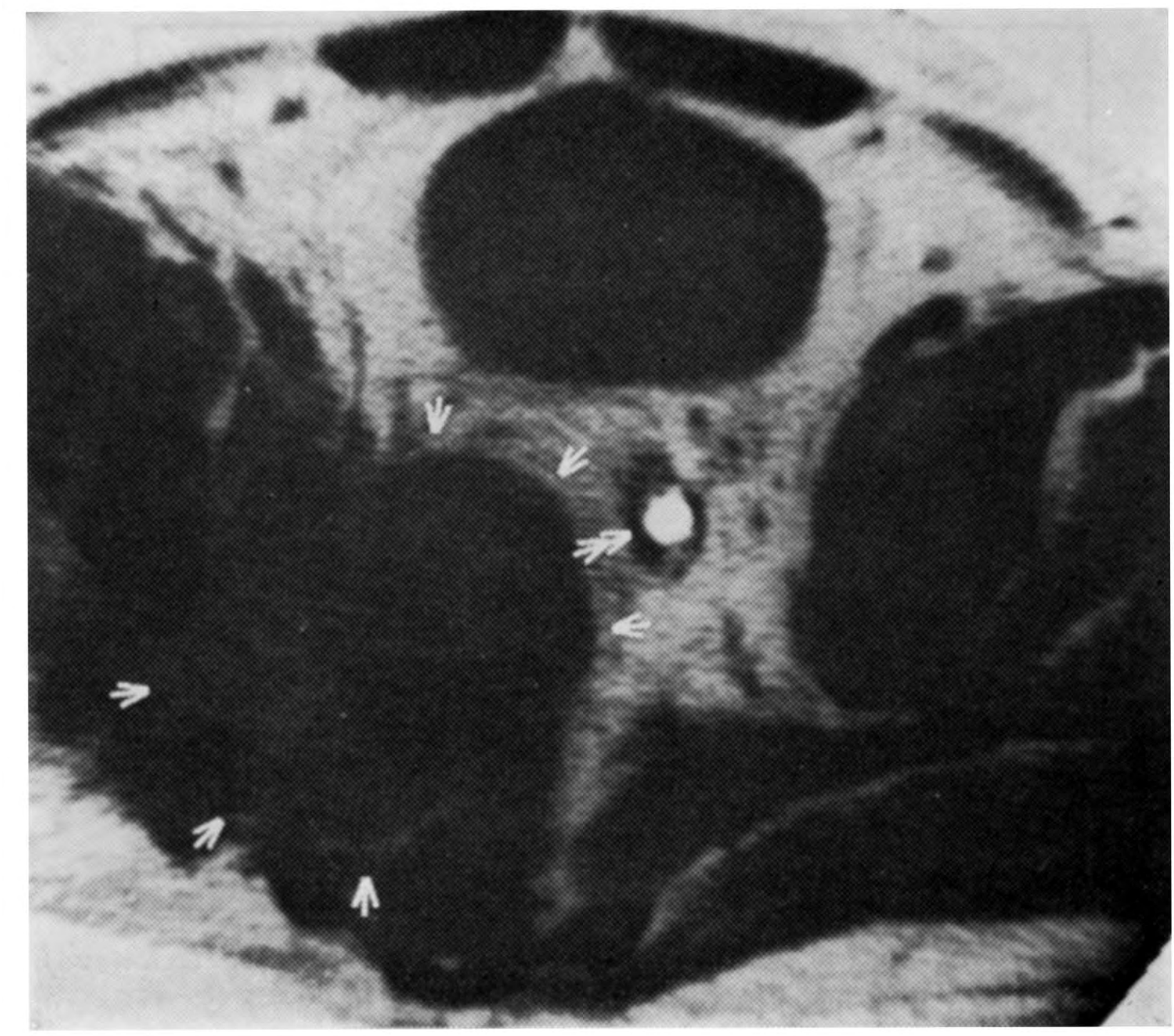

Fig. 2-Case BSB. CT-saan of the small pelvis. Arrows point to the tumor; double-arrow points to the rectum.

plegia (with proximal movements of the thigh preserved to some extent, but extremely painful) with distal amyotrophies; anesthesia of the left foot and anterolateral portions of the leg, arid diminished sensibility (both superficial and profound) on the remnant of this limb; anal sphincter spastic and painful on digital examination.

The tumor was deemed operable by a posterior transgluteal approach, which was carried out (Fig. 3). The post-operative period was uneventful. There was no motor improvement, but the pain was significantly relieved (Hitchckock's Grade 3), the patient being able to walk on crutches with no pain. He was sent to radiotherapy.

\section{COMMENTS}

1. On malignant tumors of peripheral nerves - Primary malignancy of peripheral nerves may be grouped in two main categories. First, nerve sheath tumors arising either in a previously normal nerve or from a plexiform neurofibroma of von Recklinghausen's disease, comprised of malignant schwannomas (with epithelioid and melanotic varieties), fibrosarcomas and malignant mesenchymomas. Second, neuroectodermal tumors which, while markedly rare, do occur, either of primitive type or with nerve cell differentiation. Tumors of both groups generally present themselves as a local enlargement of a nerve trunk, fusiform in shape, of fleshy consistency when accessible to palpation. They are clearly distinguished from soft tissue malignancies involving nerves secondarily, due to the characteristic fusiform enlargement of the nerve trunk in the initial stages, and to the spread of neoplasic cells along the nerve fascicles. Common sites of occurrence are the large nerves of the neck and extremities, occurring also in the retroperitoneum, viscera and cranial nerves ${ }^{4} \mathbf{- 6}$.

Adult peripheral neuroblastoma represents less than $\mathbf{1 \%}$ of all malignant primary tumors of peripheral nerves 4,5. Imunohistochemistry, electron microscopy and cytogenetics have permitted a more accurate diagnosis of adult neuroblastomas from the so-called «small dark cell tumors» group, which includes lymphomas, primitive neuroectodermal tumor, undifferentiated small cell carcinoma, Ewing's sarcoma and 


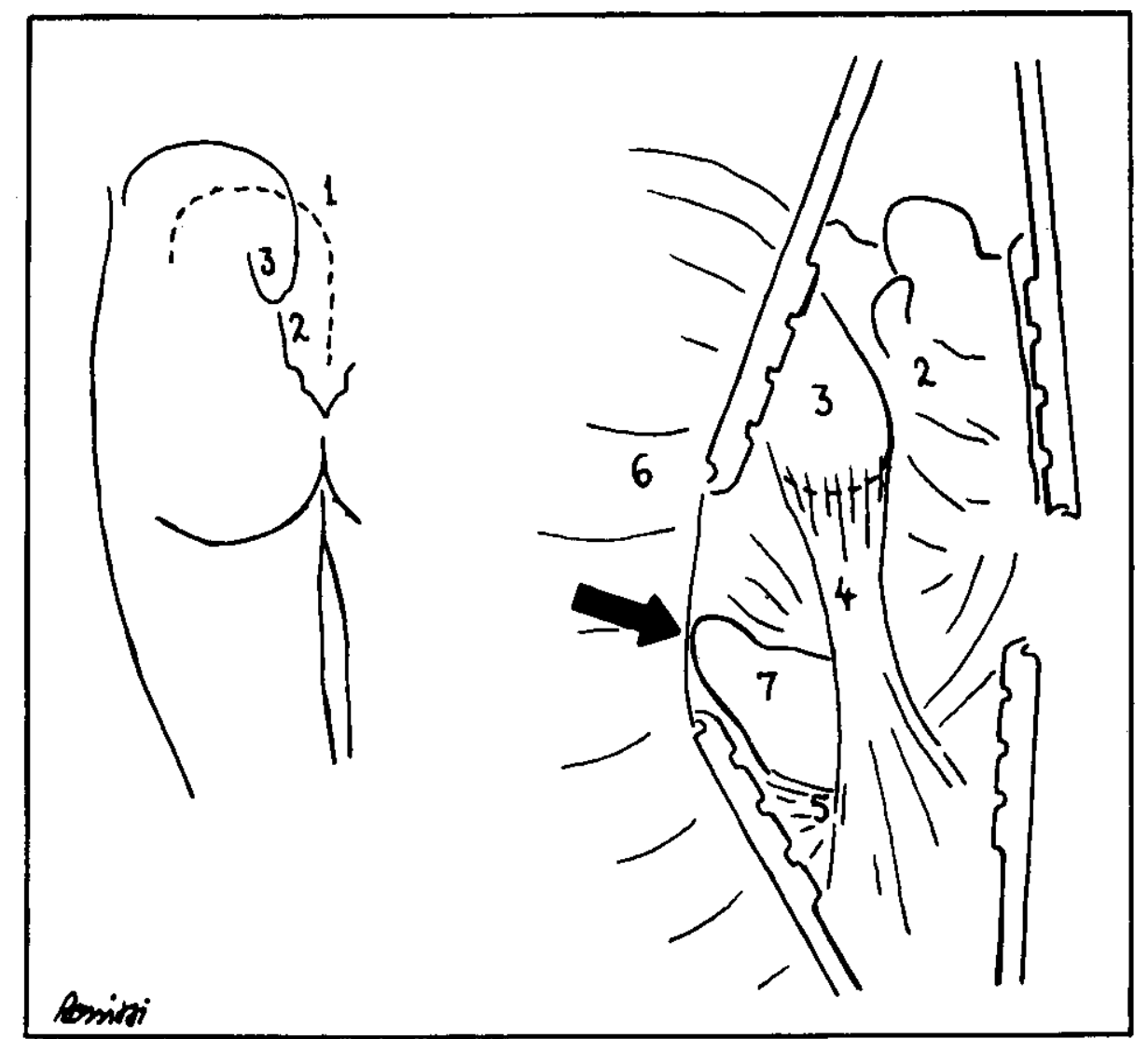

Fig. 3 - Case BCB. Transgluteal approach to small pelvis (operative technique). The skin was incised in a curved line from the iliac crest on the left, above, to the sacrum on the midline. The fascia of the $m$. erector spinae was sectioned tnansversely at the level of the posterior superior iliac spine, and detached together with the m. multifidus. The m. gluteus maximus was sectioned along the posterior iliac line of the ilium; a short extension of its fascia was left in place for later suture; its insertion on the caudial portion of the sacrum was preserved. In this manner, lateral retraction of the $m$. gluteus maximus was possible to some extent, exposing the dorsal sacroiliac, sacrotuberous and sacrospinous ligaments, and the greater sciatic foramen. The tumor infiltrated the $m$. piriformis and emerged partially through the greater sciatic foramen. The $m$. piriformis was incised, and the gray-white, semi-necrotic tumor mass was removed by aspiration until its macroscopic borderline. Integrity of the rectum was verified. After haemostasis of the tumor bed with bipolar coagulation and gelfoam, the opening was closed, the incised muscles and fasciae approximated by interrupted sutures; no drainage was necessary. 1, skin incision; 2, sacrum; 3, posterior superior iliac spine; 4, dorsal sacroiliac ligament; 5 , sacrospinal ligament; $6, \mathrm{~m}$. gluteus maximus, retracted; 7, the greater sciatic foramen, which communicates the gluteal region with the pelvis (arrow points to 7 ).

Fig. 3 - Case BCB. Transgluteal approach to small pelvis (operative technique). The skin was incised in a curved line from the iliac crest on the left, above, to the sacrum on the midline. The fascia of the $m$. erector spinae was sectioned transversely at the level of the posterior superior iliac spine, and detached together with the m. multifidus. The m. gluteus maximus was sectioned along the posterior iliac line of the ilium; a short extension of its fascia was left in place for later suture; its insertion on the caudal portion of the sacrum was preserved. In this manner, lateral retraction of the $m$. gluteus maximus was possible to some extent, exposing the dorsal sacroiliac, sacrotuberous and mcrospinous ligaments, and the greater sciatic foramen. The tumor infiltrated the $m$. piriformis and emerged partially through the greater sciatic foramen. The $m$. piriformis was incised, and the gray-white, semi-necrotic tumor mass was removed by aspiration until its macroscopic borderline. Integrity of the rectum was verified. After haemostasis of the tumor bed with bipolar coagulation and gelfoam, the opening was closed, the incised muscles and fasciae approximated by interrupted sutures; no drainage was necessary. 1, skin incision; 2, sacrum; 3, posterior superior iliac spine; 4> dorsal sacroiliac ligament; 5, sacrospinal ligament; 6, m. gluteus maximus, retracted; 7, the greater sciatic foramen, which communicates the gluteal region with the pelvis (arrow points to 7).

embryonal rhabdomyosarcoma 3,5. The most common presentation of neuroblastoma in adults is in the abdomen; involvement of a lower limb is more frequent than in children; paraspinal tumors, particularly mediastinal ones, may extend through the intervertebral foramen into the spinal canal in a dumbbell fashion 1.6.9.

Incidence is equal to both sexes, and the median age of presentation is 34 years i. There is controversy whether the survival rates of these patients parallels that of childhood neuroblastomas of a comparable stage $i$, or is worse . Radical surgical extirpation seems to be the best treatment. After aggressive surgical intercha 
Abdominopelvic or spinal neoplasic lesions are often misdiagnosed as $\wedge^{\text {herniated }}$ intervertebral disk», the actual nature of the disease becoming apparent after a considerable time. In part, the radiodiagnostic routine for patients with suspected disk disease is to blame: plain roentgenograms of the spine, and non-contrast CT-scans centered on the relevant discal interspaces, are frequently the only special ancillary diagnostic means when a «typical case» is found $\mathbf{2 , 8}$.

Abdominopelvic or spinal neoplasic lesions are often misdiagnosed as ^herniated intervertebral disk», the actual nature of the disease becoming apparent after a considerable time. In part, the radiodiagnostic routine for patients with suspected disk disease is to blame: plain roentgenograms of the spine, and non-contrast CT-scans centered on the relevant discai interspaces, are frequently the only special ancillary diagnostic means when a «typical case» is found $\mathbf{2 , 8}$.

\section{REFERENCES}

1. Allan SG, Cornbleet MA, Carmichael J, Arnott SJ, Smyth JF. Adult neuroblastoma: report of three cases and review of the literature. Cancer 1986, $57: 2419$.

2. Beltinger A, Riffel B, Stoehr M. Fehldiagnose «Lumboischialgie» bei Tumoren im Be-ᄀ reich lumbosakraler Wurzeln oder des Plexus lumbosacralis. Nervenarzt 1989, 60 : 559.

3. Dehner LP. Whence the primtive neuroectodermal tumor? Arch Pathol Lab Med 1990, $114: 16$.

4. de Matos PS, Martin CBF, Pinto JEZ. Neuroepitelioma periférico (neuroblastoma periférico) de nervo ciático. Anais do Congresso Sul-Brasileiro de Patologia, Bauru SP, 6-8 dezembro 1989, p 19 (abstr).

5. Enzinger FM, Weiss SW. Soft Tissue Tumors. St. Louis: CV Mosby, 1983, p 648.

6. Nesbitt KA, Vidone RA. Primitive neuroectodermal tumor (neuroblastoma) arising in sciatic nerve of a child. Cancer 1976, $37: 1562$.

7. Prestidge BR, Donaldson SS. Treatment results among adults with childhood tumors: a 20-year experience. Int J Radiot Oncol Biol Phys 1990, 17 : 507 (abstr).

8. Rossitti SL, Roth-Vargas AA, Sperlescu A, Balbo RJ. Radiculopatia neoplásica lumbosacral. Arq Neuro-Psiquiat (São Paulo) 1990, 48:97.

9. Urios JI, Garceran LR, Roseli TV. Neuroblastoma in an adult causing spinal cord compression: report of a case and review of the literature. Paraplegia 1989, $27: 394$. 